\title{
THE USE OF THE DSPIR FRAMEWORK TO ESTIMATE IMPACTS OF URBANIZATION ON MANGROVES: A CASE STUDY FROM LA PAZ, BAJA CALIFORNIA SUR, MEXICO
}

\author{
GIOVANNI ÁVILA-FLORES ${ }^{1}$, GUSTAVO HINOJOSA-ARANGO², \\ JUDITH JUÁREZ-MANCILLA ${ }^{3} \&$ OSCAR ARIZPE-COVARRUBIAS ${ }^{1}$ \\ ${ }^{1}$ Departamento Académico de Ciencias Marinas y Costeras, \\ Universidad Autónoma de Baja California Sur, México \\ ${ }^{2}$ CIIDIR Oaxaca, Instituto Politécnico Nacional, México \\ ${ }^{3}$ Departamento Académico de Economía, Universidad Autónoma de Baja California Sur, México
}

\begin{abstract}
The mangrove ecosystem is integrated mainly by halophytes plants that grow on coastal zones of tropical and subtropical regions. This ecosystem provides direct and indirect services for human wellbeing such as food, wood, climate regulation, natural hazard protection, recreation and aesthetic values. However, academic research indicates that more than $35 \%$ of world's mangrove coverage has been lost in the past three decades. The primary drivers of change of cover lost are aquaculture activities and development of urban infrastructure. The objective of this work was to conduct an exploratory assessment of the impacts of urbanization on mangrove communities located in the city of La Paz, Mexico using the Driver-Pressure-State-Impact-Response framework (DPSIR). The assessment was complemented by a Delphi survey to incorporate information obtained from experts and stakeholders. The results indicated that the most important pressing factors on mangrove communities were: tourism, urban growth and waste. However, the data on mangrove cover and conservation status show that the overall situation of mangroves of mangroves in La Paz is "barely adequate," with communities showing positive and adverse conditions. It is estimated that mangrove communities classified as "Vulnerable" and "Endangered" probably do not generate the same ecosystem services as mangroves classified under the "Near Threatened" and "Least Concern" categories. Protection actions as protected areas, environmental laws, and ecological restoration have helped in the conservation of mangroves in the study area. This work concludes that DPSIR framework is a handy tool to analyze in the first instance the conditions of the mangroves and may be replicable in other regions that have this ecosystem, even in places with little scientific research.
\end{abstract}

Keywords: coastal development, conservation status, DPSIR framework, drivers of change, ecosystem services, sustainability, wetlands.

\section{INTRODUCTION}

\subsection{Definition and importance of mangroves}

Mangroves can be defined as: "an ecological assemblage of trees and shrubs adapted to grow in intertidal environments along tropical coasts" [1]. According to data for the year 2000, mangroves are present in 118 countries (Figure 1), and this ecosystem had an extension of $137,760 \mathrm{~km}^{2}$ [2], [3]. However, according to Global Forest Watch (GFW), from 2001 to 2012 there was a loss of 192,000 hectares. Asia and North America were the regions with the highest losses [4].

This ecosystem, like other coastal wetlands, contributes significantly to human wellbeing. This through of the numerous ecosystem services such as provisioning (e.g. food and water), regulation and maintenance (e.g. carbon capture and storage, maintaining of nursery 


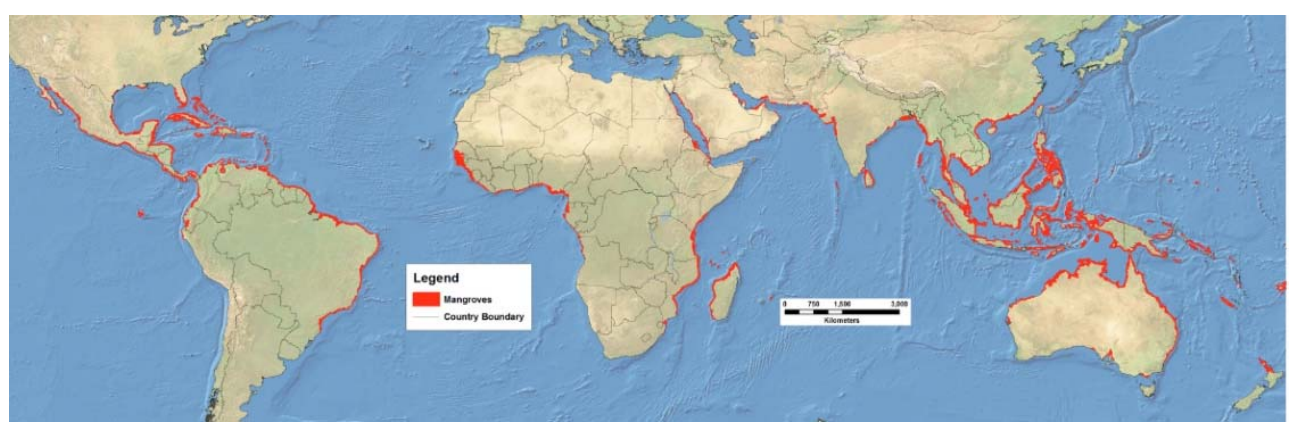

Figure 1: Distribution of mangroves in the world. (Source: UNEP-DEWA, 2013) [3].

populations and storm protection) and cultural (e.g. physical and spiritual interactions) among many others. The most recent valuation indicates that the value of mangrove services is of 193,843 USD/ha/year [5].

However, the mangroves face various threats and drivers of change. The most important are: conversion to agriculture or aquaculture, pollution, hydrological changes-indirect disturbance, exploitation, climate change and extreme weather events and coastal development [6]. This last driver originates the loss of mangrove cover for the development of diverse activities like the development of port-urban infrastructure and tourism. This situation is readily observable in regions close to coastal cities around the world.

The abundance of natural resources in the marine areas has caused that many settlements and towns to settle in the coastal zone to use them, which leads to conflicts with the surrounding ecosystems. And the city-mangrove case it is not an exception to the rule. This scenario is particularly noticeable in countries with fast population growth in coastal areas such as Mexico [7]. Perhaps, a good example of a city-environment conflict related to mangroves is the "Tajamar" case in the city of Cancun, Quintana Roo State, Mexico; where 22 hectares were destroyed due to the construction of tourist complex. This action generates numerous protests that led to the suspension of the project [8]. Also, Ezcurra mentions that due to the loss of mangroves in Quintana Roo in recent years, the Mexican government had to rebuild beaches that had been degraded by different extreme weather events [9].

\subsection{Background of DPSIR framework}

The study of issues focused on sustainability requires an integral-holistic approach; this because the same concept of sustainability considers as its core components the social, ecological and economic aspects which in themselves are already difficult subjects. Therefore, researchers and decision makers have looked for different models that consider an integrated approach and one of the most used the Driver-Pressure-State-Impact-Response framework (DPSIR).

Its origin comes from the Stress-Response framework developed by Statistics Canada in 1979. Then, Pressure-State-Response framework was originated, and afterward, the DPSIR framework was developed [10]. The use of DPSIR framework (Fig. 2) began in 2003, is designed and utilized by the European Environment Agency (EEA). Subsequently, its use was extended and is now employed by various agencies and global institutions among them the Global Environmental Outlook (GEO) reports from UNEP [11]. 


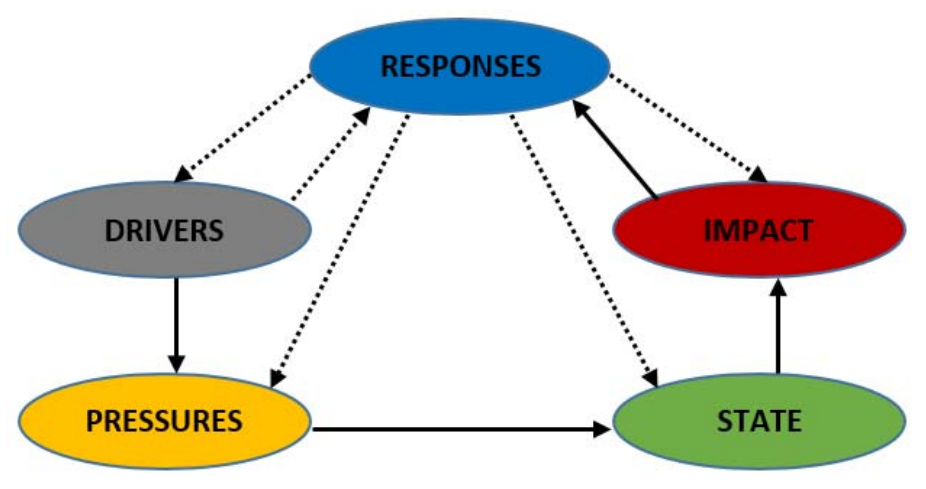

Figure 2: The DPSIR model. (Adapted from Albert et al., 2015) [17].

The DPSIR framework has confirmed a great instrument to understand the relationships between the environment and society and have been used in diverse ways. For instance, this structure has helped to bridge the gap between science and policy, especially in the case of coastal zone management [12]. Also, this tool has been used to examine the role of the major coastal cities in the environmental degradation of their nearby ecosystems as well as their repercussions to climate change [13].

In the case of wetlands, the framework was used to analyze changes in coastal wetlands in Xiamen, China [14]. Another study used this approach to estimate anthropic impacts on the coastal ecosystems of Berau, East Kalimantan, Indonesia and identified as a pressure indicator to mangrove conversion and overexploitation [15]. In this regard, the framework was used in the assessment of the mangrove community "Enfermería" located in the Bay of La Paz, Gulf of California, Mexico [16].

\section{Methodology}

\subsection{Study area}

The study area is comprised of 16 mangrove communities which are within of the limits of La Paz city according to its urban development plan. This settlement is situated to the southeast of the Baja California Peninsula (placed in the northwest of Mexico) and is the capital of Baja California Sur State (Fig. 3). The city is located in the DMS latitude-longitude coordinates $24^{\circ} 08^{\prime} 32^{\prime \prime} \mathrm{N} 110^{\circ} 18^{\prime} 39^{\prime \prime} \mathrm{W}$; belongs to the Municipality of the same name, and borders to the north with the Municipality of Comondú and the southern limits with the Municipality of Los Cabos. On the east by La Paz Bay, Gulf of California and on the west by the Pacific Ocean [18].

The climate of this city, according to the classification of Köppen, modified by E. García is BW (h') w. It is classified as very warm and arid: with an average annual temperature greater than $22^{\circ} \mathrm{C}$ and average over $18^{\circ} \mathrm{C}$ for the coldest month, with rainfall predominant in summer and between 5 and $10.2 \%$ of the total rains occur during the winter period.

Originally its economic activities were mainly based on fishing and trade, although in recent years the tourism and services activity has increased considerably, due to the beauty of its natural landscapes, particularly coastal areas [19]. Also, La Paz is an important seaport of northwest Mexico. Its particular geographic and climatic conditions have allowed to the 
area to have a significant number of natural resources, especially services provided by coastal ecosystems as coastal plains, coastal dunes, sandy beaches, sandbars and mangroves [20].

\subsection{Research procedures}

The DPSIR framework was used to identify the drivers of change affecting mangroves, to estimate their effects on the ecosystem services offered by these wetlands and to determine the measures used for their conservation in the city of La Paz.

Within this framework, the drivers are factors that exert pressures on the environment, and such forces can cause changes in their state. Consistent impacts on ecosystem services trigger a societal response to developing or changing environmental policies and developing programs to prevent, minimize or mitigate the pressures and driving forces. To feed this outline, we reviewed and compiled literature related to the mangrove communities of the City of La Paz (focusing on the period 1970-2015). In particular, an analysis of the literature was made in publications such as scientific articles, technical reports, scientific conference reports, theses, etc.

\subsection{Delphi method}

Preferably, the groups of experts and stakeholders should be together to identify the DPSIR variables and to lay their pathways. However, due to limitations of time and technical constraints in the research, the opinions were gathered from one-off questionnaires and personal interviews. Information from a desktop study was used to develop the surveys.

The survey was prepared in two types, for stakeholders and experts. In some cases that were needed prioritization, the questionnaire followed a Likert scale, where the statements that have to be scored, this measure comprised between 1 (bad) to 10 (good), by the respondents.

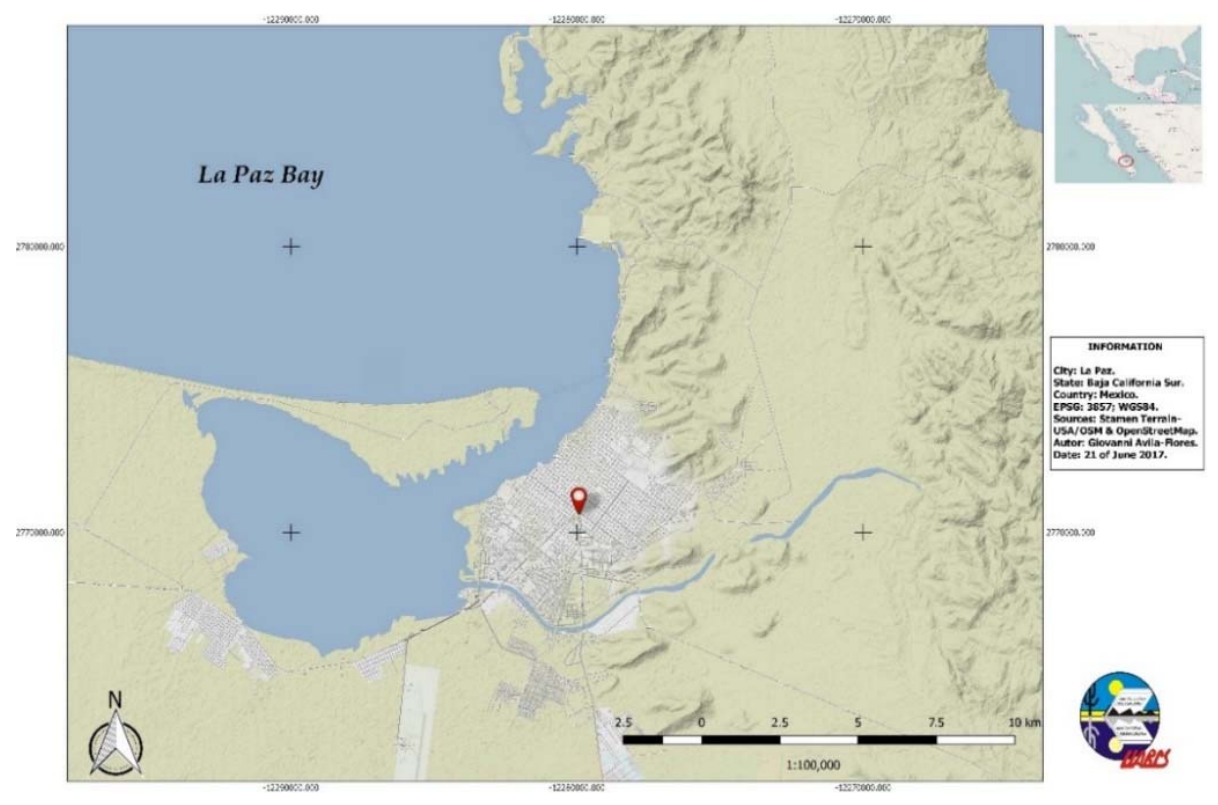

Figure 3: Map of La Paz city: area of study. 
Table 1: DPSIR indicators for estimation of the state of mangroves in La Paz. (Adapted from Xu et al., 2015) [23].

\begin{tabular}{c|llc}
\multicolumn{1}{c}{ Modules } & \multicolumn{1}{c}{ Indicator } & \multicolumn{1}{c}{ Description } \\
\hline Driver & Human development index & Measure of HDI & QL \\
& Population & Demographic evolution & QL \\
& Climate change & Estimation of future effects & QL \\
Pressure & Tourism & Number of tourist arrivals & QL \\
& Urban growth & Effects of infrastructure development & QL \\
& Waste & Effects of waste disposal cilones & QL \\
& Meteorological phenomena & Affectation of destructive cyclones & QL \\
& Sea level rise & Total vulnerability to sea rise & QL \\
State & Mangrove cover & Changes in mangrove cover & QT \\
& Conservation status & Establishment of categories of risk & QT \\
Respoct & Loss of ecosystem services & Estimation of loss of ecosystem services & QL \\
& Protected Areas & Surface and types of protected areas & QL \\
& Environmental Legislation & Number of laws related to mangroves & QL \\
& Ecological restoration & Number of restoration projects & QL \\
\hline
\end{tabular}

Note: HDI, Human Development Index; QL, qualitative assessment; QT, quantitative assessment.

\section{RESEARCH PROCESS AND RESULTS}

Through the application of DPSIR framework, three indicators were identified in the Drivers Module, five in the Pressure Module, two in the State Module, one in the Impact Module and three in the Responses Module (Table 1). The framework has been generated mainly on three aspects: 1) the availability of data, 2) the approaches of various experts on DPSIR with studies on coastal wetlands, and 3) assessments of local stakeholders [21]-[23]. Each of these modules, as well as their indicators, are explained in more detail above.

\subsection{Drivers}

Human Development Index: In 2010, La Paz is the municipality with the highest human development index (HDI) in Baja California Sur (BCS), with a value of 0.816 [24].

Population: The city of La Paz, population for the year 2015 was approximately 244, 219 inhabitants. In 1990, the number of residents was 137, 641, in 2000 it was 162, 954 and in 2010 it was 215,178 . This increase is due to this city has been an important magnet for internal immigration in recent years; although the intensity of these flows has been reduced [25].

Climate change: The Mexican Report on Climate Change report that mangrove communities in Mexico are highly vulnerable to any shift in elevation sea as well as by hurricanes [26]. It includes to mangroves located in La Paz city too. This situation would cause a significant loss of ecosystem services, but this would vary according to the projected scenario.

\subsection{Pressure}

Tourism: Tourism is one of the main components of the local development and generates a substantial economic revenue. Tourism showed a decrease in the number of visitors in 2010 $(1,622,179)$ compared to $2008(2,150,095)$ and $2014(1,740,469)$ but a recovery was observed in recent years. On the other hand, in the past, the development of tourism sector 
affected some mangroves areas, and the development of new projects could put to these wetlands at risk [27].

Urban growth: The development of urban infrastructure along the coast of the city of La Paz has caused disturbances in mangroves during the last 30 years. The construction of the road to the port of Pichilingue in the 1960s caused impacts to several mangrove communities such as "Pichilingue-Brujas," "Enfermería" and "Eréndira." Similarly, housing developments have affected the "El Conchalito" mangrove, as well "Palmira" [28].

Waste: Riosmena-Rodríguez report that the residues found in mangroves of La Paz vary from rotten food, plastic-glass bottles, tires, diapers, aluminum cans, and. Even, in these communities, there have been spills of sewage, fuel, and oil-asphalt [29].

Meteorological phenomena: Although La Paz presents a high incidence of cyclones year after year, the scientific evidence is scarce to conclude that there have been changes in the cyclonic activity caused by climate change. However, in September 2014, Hurricane Odile impacted the coasts of this state, resulting in severe consequences that led to social unrest and significant economic losses. Moreover, the effects on mangroves are ignored [30].

Sea level rise: The Climate Action Plan for the state of BCS, report that in reason to its index of total vulnerability, La Paz obtained a value of 2.0. This result makes it the second most vulnerable site in BCS to sea level rise, only below of Los Cabos that obtained a value of 2.4 [31].

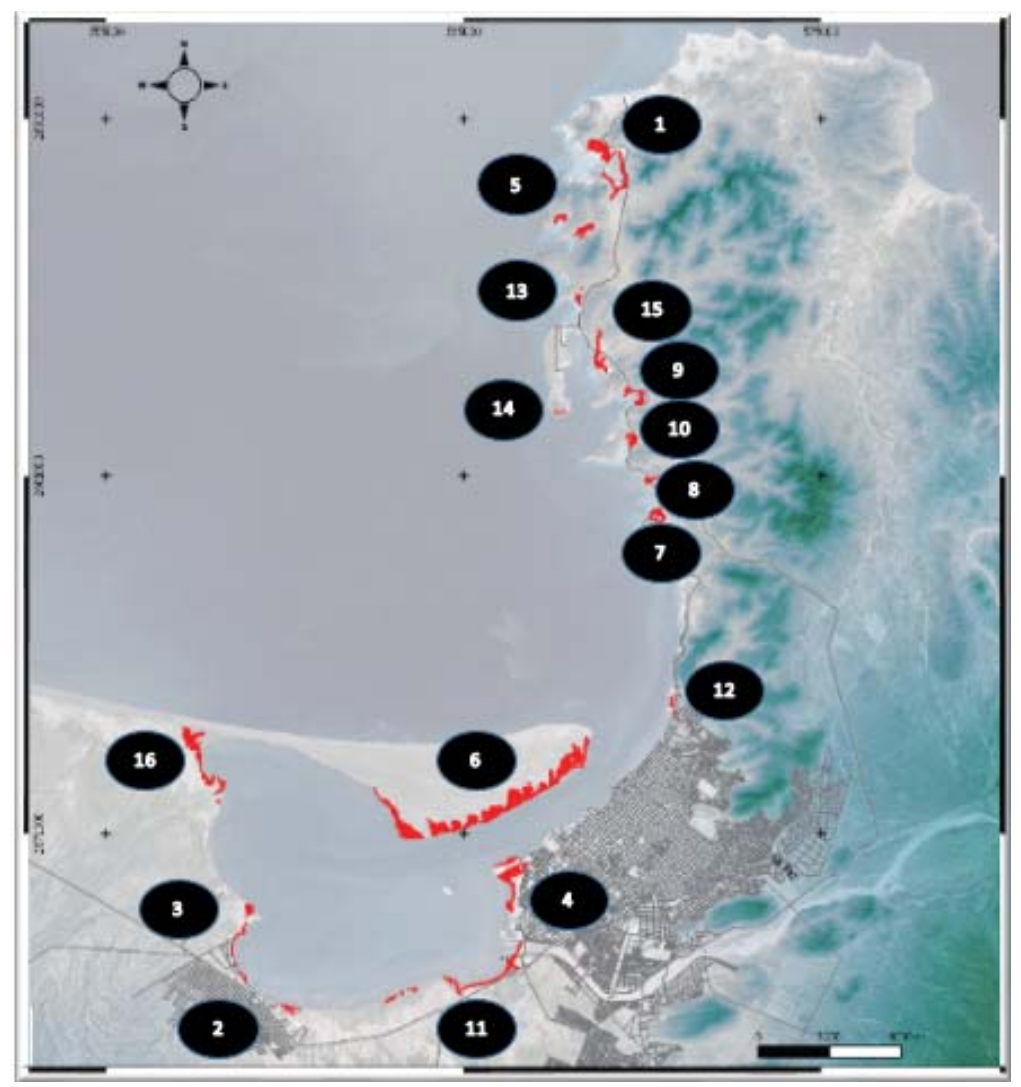

Figure 4: Location of mangrove communities situated in the city of La Paz. 


\subsection{State}

Mangrove Cover: Avila-Flores [32] reports the mangrove cover of the town of La Paz for the year 2014 is estimated at approximately 25.91 hectares (Fig. 4). Moreover, in 1973 there was a mangrove cover of 22.70 hectares. This result represented an increase in mangrove cover of 3.21 hectares over a period of 30 years (an increase of $14 \%$ ). It should be noted that in 10 of the 16 communities there were losses of cover, five presented increases and one without changes.

Conservation Status: Seven mangrove communities were classified under the "Least Concern" category, other seven under the "Near Threatened" category, one under the "Vulnerable" category and another in the type "Endangered" (Table 2). These results were obtained considering aspects of mangrove cover and expert analysis. And using the classification "Red List for Ecosystems" of the International Union for Conservation of Nature and Natural Resources (IUCN) [32].

\subsection{Impact}

Loss of ecosystem services: So far, no scientific research has evaluated the loss of ecosystem services in the study area, although there are several methods for estimating mangrove services [33]. However, is considered that disturbed mangroves in the area, such as "Enfermería" and "Pichilingue-Brujas" not have the same value as other mangroves such as "Balandra" and "El Merito" which have a better conservation status.

Table 2: Conservation status of mangroves from La Paz.

\begin{tabular}{l|l|c|}
\hline$\#$ & Mangrove communities & Categories of risk IUCN \\
\hline 1 & Balandra & Least Concern \\
2 & Centenario-Chametla & Least Concern \\
3 & Comitán & Least Concern \\
4 & El Conchalito & Near Threatened \\
5 & El Merito & Least Concern \\
6 & El Mogote & Near Threatened \\
7 & Enfermería & Vulnerable \\
8 & Eréndira & Near Threatened \\
9 & Estero Bahía Falsa & Least Concern \\
10 & Estero El Gato & Least Concern \\
11 & La Paz-Aeropuerto & Near Threatened \\
12 & Palmira & Near Threatened \\
13 & Playa Pichilingue-Brujas & Endangered \\
14 & Salinas de Pichilingue & Near Threatened \\
15 & Unidad Pichilingue UABCS & Near Threatened \\
16 & Zacatecas & Least Concern \\
\hline
\end{tabular}




\subsection{Responses}

Protected areas: In this respect, all mangroves located within the coverage of the city of La Paz are under this scheme. One of them is the Ramsar Site No. 1.816 "Wetlands MogoteEnsenada de La Paz" which has an area of 9,184.07 hectares (ha) and was designated as a coastal wetland of international importance on February 2, 2008. The other protected area is "Balandra" which is an extent under the Federal category. The publication of its decree was on November 30, 2012. This zone holds an area of 2,512 ha, and this is designated as a Ramsar Site too.

Environmental legislation: There is a significant number of laws and regulations that protect mangroves both directly and indirectly. At least there are 14 legal instruments to give protection to mangroves in the area [34]. The most important norm is the NOM-022SEMARNAT-2003. This standard establishes that "productive activities such as agriculture, intensive or semi-intensive aquaculture, urban infrastructure, must leave a minimum distance of $100 \mathrm{~m}$ concerning the limit of vegetation (mangrove), in which productive activities will not be allowed" [35].

Ecological restoration: Efforts have been made by the civil society to remove solid waste from the city's beaches and nearby mangroves. However, only two cases could be considered as ecological rehabilitation of mangroves. One was developed in 2004 because of adverse impacts of a hurricane on the mangrove community "El Mogote." [36]. The other restoration project was carried out in 2013 in the mangrove community "Enfermería" by the Department of Ecology and Environment of the State Government of Baja California Sur, along with other academic institutions such as CIBNOR and local volunteers. This last project was carried out due to a requirement indicated by the Secretariat of Environment and Natural Resources of Mexico (SEMARNAT) of the contiguous project "Center of Conventions of the city of La Paz."

\section{FINAL REMARKS}

Although the scope of the DPSIR framework may be limited, it offers a critical initial approach and is a basis for further studies as well as the development of indicators for continuous monitoring. In this regard, it is considered that this tool has potential to be applied in coastal management because it can be implemented in different geographic areas and helps the analysis of complex zones systems [37]. Drivers such as economic development and population growth have been key factors in affecting mangroves, but climate change is expected to play a greater role in the area. In the past, urban growth was the most impacting factor in these communities and to a lesser extent were tourism and waste generation. However, it is surprising that there was no loss of mangrove cover, but instead, there was a slight increase. Moreover, this fact is possibly due to strict public policies on mangrove conservation. And an example is that all the mangroves of this zone are under the legal cover of a protected area. Finally, it is necessary to improve or maintain the conservation status of the mangroves in this region and the development of projects that consider the sustainable use of these ecosystems will undoubtedly be of vital importance to achieve a fair and sustainable local development.

\section{ACKNOWLEDGEMENTS}

This paper is based on Avila-Flores, (2016). The first author states support for this work was provided by National Council of Science and Technology (CONACYT) through scholarship No. 387590 to complete his postgraduate studies. In memoriam: Dr. Rafael Riosmena Rodríguez. 


\section{REFERENCES}

[1] Feller, I.C., C.E., Lovelock, U., Berger, K.L., McKee, S.B., Joye, S.B. \& Ball, M.C., Biocomplexity in mangrove ecosystems, Annu. Rev. Mar. Sci., 2, pp. 395-417, 2009.

[2] Giri, C., Ochieng, E., Tieszen, L. L., Zhu, Z., Singh, A., Loveland, T., Masek, J. \& Duke, N., Status and Distribution of Mangrove Forests of the World Using Earth Observation Satellite Data. Global Ecology and Biogeography, 20, pp. 154-159, 2011.

[3] Mangrove forest cover fading fast; United Nations Environment Programme (UNEP), Division of Early Warning and Assessment (DEWA), Online, https://na.unep.net/geas/articleimages/Aug-13-figure-1.png. Accessed on: 18 Mar. 2017.

[4] Satellite Data Reveals State of the World's Mangrove Forests; Global Forest Watch, World Resources Institute Online, http://www.wri.org/blog/2015/02/satellite-datareveals-state-world\%E2\%80\%99s-mangrove-forests. Accessed on: 29 Jun. 2017.

[5] Costanza, R., de Groot, R., Sutton, P., van der Ploeg, S., Anderson, S.J., Kubiszewski, I., Farber, S., \& Turner, R.K., Changes in the global value of ecosystem services. Global Environmental Change, 26, 152-158, 2014.

[6] van Bochove, J., Sullivan, E., \& Nakamura, T. eds. The importance of mangroves to people: A call to action. Cambridge: United Nations Environment Programme-World Conservation Monitoring Centre, pp. 69-73, 2014.

[7] Ortiz-Lozano, L., Granados-Barba, A., Solís-Weiss, V. \& García-Salgado, M.A., Environmental evaluation and development problems of the Mexican Coastal Zone. Ocean \& Coastal Management, 48(2), pp. 161-176, 2005.

[8] Judge grants final suspension of works in Tajamar; La Jornada, Online, http://www.jornada.unam.mx/ultimas/2016/02/02/conceden-suspension-definitivacontra-obras-en-tajamar-cancun-9880.html. Accessed on: 28 Jun. 2017.

[9] Wild urbanization impacts ecosystems and human security; Crónica, Online, http://www.cronica.com.mx/notas/2017/1033364.html. Accessed on: 17 Jul. 2017.

[10] Gari, S.R., Newton, A. \& Icely, J. D., A review of the application and evolution of the DPSIR framework with an emphasis on coastal social-ecological systems. Ocean \& Coastal Management, 103, pp. 63-77, 2015.

[11] Ajero, M.A., Armenteras, D., Barr, J., Barra, R., Baste, I., Dobrowolski, J., Dronin, N., et al., Global Environment Outlook (GEO-5). United Nations Environment Programme, Nairobi, p. 5, 2012.

[12] Lewison, R. L., Rudd, M. A., Al-Hayek, W., Baldwin, C., Beger, M., Lieske, S. N., et al., How the DPSIR framework can be used for structuring problems and facilitating empirical research in coastal systems. Environ. Sci. Policy, 56, pp. 110-119, 2016.

[13] Sekovski, I., Newton, A. \& Dennison, W.C., Megacities in the coastal zone: Using a driver-pressure-state-impact-response framework to address complex environmental problems. Estuarine Coastal and Shelf Science, 96, pp. 48-59, 2012.

[14] Lin, T., Xue, X.Z. \& Lu, C.Y., Analysis of coastal wetland changes using the 'DPSIR' model: a case study in Xiamen, China. Coastal Management, 35, pp. 289-303, 2007.

[15] Vermaat, J.E., Estradivari, E. \& Becking, L.E., Present and future environmental impacts on the coastal zone of Berau (East Kalimantan, Indonesia), a deductive scenario analysis. Reg. Environ. Chang, 12, pp. 437-444, 2012.

[16] Avila-Flores, G., \& Riosmena-Rodriguez, R., Integrated environmental assessment and scenarios of mangrove community in the Gulf of California case study 'Manglar Enfermería'. In: Riosmena-Rodriguez, R., López-Vivas, J. M. \& Hinojosa-Arango, G. 
eds, The Arid Mangrove Forest from Baja California Peninsula. Nova Publishers, New York, 2, pp. 131-150, 2016.

[17] Albert, C., Galler, C., Hermes, J., Neuendorf, F., von Haaren, C. \& Lovett, L., Applying ecosystem services indicators in landscape planning and management: The ES-in-Planning framework. Ecological Indicators, 16, pp. 100-113, 2016.

[18] General information about the port of La Paz BCS; Secretariat of the Navy, Online, http://digaohm.semar.gob.mx/cuestionarios/cnarioLapaz.pdf. Accessed on: 26 Jun. 2017.

[19] Juárez-Mancilla, J., Cruz-Chávez, G.R., Cruz-Chávez, P.R. \& Torres-García, A.F., Sustainable regional development and tourism in Baja California Sur. In: JuárezMancilla, J., Cruz-Chávez, P.R., Torres-García, A.F., Orozco-Plascencia. \& BravoSilva, J.L., eds, Perspectives of sustainable and competitive tourism development in states of Mexican Pacific. Ediciones de la Noche, La Paz, pp. 29-30, 2017.

[20] González-Baheza, A. \& Arizpe-Covarrubias, O., Vulnerability assessment for supporting sustainable coastal city development: a case study of La Paz, Mexico. Climate and Development, pp. 1-17, 2017. DOI:10.1080/17565529.2017.1291406

[21] Lin, T., Xue, X.Z. \& Lu, C.Y., Analysis of coastal wetland changes using the "DPSIR" model: a case study in Xiamen, China. Coastal Management, 35, pp. 289-303, 2007.

[22] Kelble, C.R., Loomis, D.K., Lovelace, S., Nuttle, W. K., Ortner, P.B., Fletcher, P., Cook, G., Lorenz, J. J. \& Boyer, J.N., The EBMDPSER conceptual model: Integrating ecosystem services into the DPSIR framework. PLoS ONE, 8(8), pp. 1-8, 2013.

[23] Xu, E. Leung, K. Morton, B. \& Lee, J., An integrated environmental risk assessment and management framework for enhancing the sustainability of marine protected areas: The Cape d'Aguilar Marine Reserve case study in Hong Kong. Science of the Total Environment, 505, pp. 269-281, 2015.

[24] Anonymous, Municipal Human Development Index in Mexico: new methodology, Mexico, pp. 40-41, 2014.

[25] Baja California Sur State Development Plan 2015-2021; State government of Baja California Sur, Online, http://www.bcs.gob.mx/docs/PED2015-2021_DIGITAL.pdf. Accessed on: 27 Jun. 2017.

[26] Escobar-Briones, E., Ocean Systems. In: Gay y García, C., \& Rueda-Abad, J.C. (eds), Mexican climate change report. UNAM, Mexico, 2, pp. 59-72, 2015.

[27] Tourist Information by Federal Entity: Baja California Sur; Ministry of Tourism, Online, http://www.datatur.sectur.gob.mx/ITxEF/ITxEF BCS.aspx. Accessed on: 25 Jun. 2017.

[28] Guzmán, J.R., Wetlands. In: Mahieux, S., (ed), Environmental diagnosis of Baja California Sur. FUNDEA-UABCS-NIPARAJA, La Paz, pp. 331-334, 1998.

[29] Riosmena-Rodríguez, R. Personal communication, 7 December 2015, Head of Marine Botany Laboratory, UABCS, La Paz, Mexico.

[30] Breña-Naranjo, J. A., Pedrozo-Acuña, A., Pozos-Estrada, O., Jiménez-López, S. A. \& López-López, M., The contribution of tropical cyclones to rainfall in Mexico. Phys. Chem. Earth, 83-84, pp. 111-122, 2015.

[31] Ivanova, A., \& Gámez, A. eds, Climate action plan for the state of Baja California Sur. UABCS-CICIMAR-CIBNOR-SEMARNAT-INE, Mexico, pp. 47-49, 2012.

[32] Avila-Flores, G., Diagnosis of the conservation status of mangroves in the city of La Paz, Baja California Sur, Mexico. (Master dissertation). Retrieved from https://www.researchgate.net/publication/317592856_Diagnostico_del_Estado_de_C 
onservacion_de_los_Manglares_de_la_Ciudad_de_La_Paz_Baja_California_Sur_Me xico, 2016.

[33] Vo, Q.T., Kuenzer, C., Vo Quang, M., Moder, F. \& Oppelt, N., Review of valuation methods for mangrove ecosystem services. Ecological Indicators, 23, pp. 431-446, 2012.

[34] Avila-Flores, G., Hinojosa-Arango, G., Pérez-Cortés, H. \& Juárez-Mancilla, J., Observations on the effects of public policy in the conservation status of mangrove communities: a case study "La Paz Bay, Gulf of California." Presented at 5th National Research Seminar: Public Policies, Economic Development, and Sustainability, Cabo San Lucas, Mexico, 2017.

[35] SEMARNAT, NOM-022-SEMARNAT-2003 that establishes specifications for the preservation, conservation, sustainable use and restoration of coastal wetlands in mangrove areas. Diario Oficial de la Federación, Apr. 10, 2003.

[36] Bashan, Y., Moreno, M., Salazar, B.G. \& Alvarez, L. Restoration and recovery of hurricane-damaged mangroves using the knick point retreat effect and tides as dredging tools. Journal of Environmental Management, 116, pp. 196-203, 2013.

[37] Patrício, J., Elliott, M., Mazik, K., Papadopoulou, K.N. \& Smith, C.J., DPSIR - Two decades of trying to develop a unifying framework for marine environmental management? Front. Mar. Sci., 3,177., pp. 1-14, 2016. 